\title{
Correction to: Metformin ameliorates scleroderma via inhibiting Th17 cells and reducing MTOR-STAT3 signaling in skin fibroblasts
}

Jeonghyeon Moon ${ }^{1 \dagger}$, Seon-yeong Lee ${ }^{2 \dagger}$, Jeong Won Choi ${ }^{2}$, A. Ram Lee ${ }^{2,3}$, Jin Hee Yoo ${ }^{2}$, Su-Jin Moon ${ }^{4}$, Sung-Hwan Park ${ }^{5}$ and Mi-La Cho $1,2,3,6^{*}$ (D)

\section{Correction to: J Transl Med (2021) 19:192}

https://doi.org/10.1186/s12967-021-02860-z

In the original publication [1] there was an incorrect funding section. The incorrect and correct funding information is published in this correction article. The original article has been updated.

\section{Incorrect funding}

- This research was supported by a grant of the Korea Health Technology R\&D Project through the Korea Health Industry Development Institute (KHIDI) funded by the Ministry of Health \& Welfare, Republic of Korea (Grant Number HI20C1496), the National Research Foundation of Korea (NRF) grant funded by the Korea government (MSIT) (No. NRF-2018R1A2B6007291) and (No. NRF2018R1C1B6005889).

The original article can be found online at https://doi.org/10.1186/s12967021-02860-z.

*Correspondence: iammila@catholic.ac.kr

†Jeonghyeon Moon and Seon-yeong Lee contributed equally to this work

${ }^{2}$ Rheumatism Research Center, College of Medicine, Catholic Research Institute of Medical Science, The Catholic University of Korea, 222

Banpo-Daero, Seocho-gu, Seoul 06591, Republic of Korea

Full list of author information is available at the end of the article

\section{Correct funding}

- This research was supported by a grant of the Korea Health Technology R\&D Project through the Korea Health Industry Development Institute (KHIDI) funded by the Ministry of Health \& Welfare, Republic of Korea (Grant Number HI20C1496, HI15C3062), the National Research Foundation of Korea (NRF) grant funded by the Korea government (MSIT) (No. NRF-2018R1A2B6007291) and (No. NRF-2018R1C1B6005889).

\footnotetext{
Author details

'Lab of Translational ImmunoMedicine, Catholic Research Institute of Medical Science, College of Medicine, The Catholic University of Korea, Seoul 06591 , Republic of Korea. ${ }^{2}$ Rheumatism Research Center, College of Medicine, Catholic Research Institute of Medical Science, The Catholic University of Korea, 222 Banpo-Daero, Seocho-gu, Seoul 06591, Republic of Korea. ${ }^{3}$ Department of Biomedicine \& Health Sciences, College of Medicine, The Catholic University of Korea, 222, Banpo-daero, Seocho-gu, Seoul 06591, Republic of Korea. ${ }^{4}$ Divison of Rheumatology, Department of Internal Medicine, Uijeongbu St. Mary's Hospital, College of Medicine, The Catholic University of Korea, Uijeongbu 11765, Republic of Korea. ${ }^{5}$ Division of Rheumatology, Department
} 
of Internal Medicine, Seoul St. Mary's Hospital, College of Medicine, The Catholic University of Korea, Seoul 06591, Republic of Korea. ${ }^{6}$ Department of Medical Lifescience, College of Medicine, The Catholic University of Korea, 222, Banpo-daero, Seocho-gu, Seoul 06591, Republic of Korea.

Published online: 21 June 2021

\section{Reference}

1. Moon J, Lee S, Choi JW, Lee AR, Yoo JH, Moon S-J, Park S-H, Cho ML. Metformin ameliorates scleroderma via inhibiting Th17 cells and reducing
mTOR-STAT3 signaling in skin fibroblasts. J TransI Med. 2021;19:192. https://doi.org/10.1186/s12967-021-02860-z.

\section{Publisher's Note}

Springer Nature remains neutral with regard to jurisdictional claims in published maps and institutional affiliations.
Ready to submit your research? Choose BMC and benefit from:

- fast, convenient online submission

- thorough peer review by experienced researchers in your field

- rapid publication on acceptance

- support for research data, including large and complex data types

- gold Open Access which fosters wider collaboration and increased citations

- maximum visibility for your research: over $100 \mathrm{M}$ website views per year

At BMC, research is always in progress.

Learn more biomedcentral.com/submissions 